\title{
Dilemmas and Solutions of Sponge City Construction in Jiangsu Province
}

\author{
Jun $\mathrm{Xu}^{*}$ \\ Business School \\ Jiangsu Normal University \\ Xuzhou 221110. China \\ *Corresponding author
}

\author{
Qian Jia \\ Business School \\ Jiangsu Normal University \\ Xuzhou 22110. China
}

\author{
Xingcheng Ge \\ Business School \\ Jiangsu Normal University \\ Xuzhou 22110. China
}

\begin{abstract}
With continuous aggravation of urban ecological problems, the problems including regional water resources shortage, water environment deterioration, water ecological degradation and frequent internal flood and waterlogging in Jiangsu province are becoming more and more serious. Promoting the construction of sponge city is an effective way to solve the water problems. Taking Jiangsu province as the research object, through investigation and literature research, it is concluded that there are some dilemmas in Jiangsu province, such as imperfect laws and regulations on sponge city construction, insufficient cognition of sponge city construction concept, insufficient management system, inadequate technical level, and large regional differences between north and south. Combined with the actual situation of Jiangsu province, this paper puts forward reasonable solutions from the macro, middle and micro perspectives, hoping to provide some reference for the construction of sponge city in Jiangsu province.
\end{abstract}

Keywords-Jiangsu province; Sponge cities; Dilemmas; Solutions

\section{INTRODUCTION}

The 19th report proposed to "build China into a strong, prosperous, democratic, culturally advanced, harmonious and beautiful modern socialist country", highlighting the importance of ecological environment. Sponge city is an important form of urban development and transformation in China and one of the goals of "ecological civilization construction". At present, many cities in China have set off a wave of sponge city construction. In November 2014, the ministry of housing and urban-rural development of China issued "the technical guide for sponge city construction". At the beginning of 2015, Zhenjiang of Jiangsu province became one of the first 16 sponge pilot cities. Chairman and premier have repeatedly put forward clear requirements on sponge city construction, which are highly valued by the CPC central committee and the state council.

"Sponge" has the function of adsorption. Population researcher Budge uses sponge to describe the phenomenon of urban population adsorption ${ }^{[1]}$. "Sponge city" refers to a city that, like a sponge, can absorb water, store water, seep water and purify water when it rains, and "release" and utilize the stored water when needed ${ }^{[2]}$. Due to frequent floods and waterlogging disasters in China, scholars began to learn advanced concepts of rain-flood management from foreign countries and introduced "sponge city" into the mainland of China. The construction of sponge city in China started in 2013

In recent years, the economic development of Jiangsu province is thriving. It ranks second in the province, second only to Guangdong province. With the development of economy, people's living standards are constantly improving, and urbanization is at a high level. On the one hand, it leads to increased pressure on urban water use and increased household garbage, posing a threat to urban ecological environment. On the other hand, urban infrastructure is relatively traditional. In addition, Jiangsu province has a monsoon climate, with heavy and concentrated precipitation and heavy rainfall in summer, while Jiangsu province is low-lying, which is not conducive to flood discharge, resulting in increased flood disasters. In order to solve the problem of urban water, various regions and departments concerned actively explore and practice. In August 2016, Jiangsu province approved Nanjing, Xuzhou, Changzhou, and Suzhou to become provincial-level pilot cities. In August 2017, Jiangsu province's first innovative government regulation on sponge city construction and management Zhenjiang sponge city management measures was officially implemented, indicating that the construction of sponge city in Jiangsu province is imperative. Jiangsu province has set the goal of sponge city construction in the next ten years: more than 80 percent of the built area should meet the requirements of sponge city construction. We are far from the requirements of sponge city construction. The problems of regional water resource shortage, water environment deterioration, water ecological degradation and frequent urban flooding in Jiangsu province are becoming more and more serious. As the capital of Jiangsu province, Nanjing has a serious problem of "rain and waterlogging". The shortage problem of water in Zhenjiang is prominent, water resources pollution is worrying; Seasonal urban waterlogging occurs frequently in southern Jiangsu, and excessive hardening of the ground leads to water ecological degradation. Therefore, taking this as the starting point, this paper focuses on the study of the problems existing in the construction of sponge city in Jiangsu province, and puts forward reasonable solutions from the macro, middle and micro perspectives, hoping to provide certain reference for the construction of sponge city in Jiangsu province. 


\section{THE DILEMMAS OF SPONGE CITY CONSTRUCTION IN JIANGSU PROVINCE}

\section{A. The laws and regulations are imperfect}

The national policy system plays an important role in promoting the construction of sponge city in Jiangsu province. The policies of government departments play a leading role in the construction of sponge city. The planning, construction and maintenance of sponge city are all controlled by the government, and the government's capital investment and policy inclination become the most important driving force for the construction of sponge city ${ }^{[3]}$.

In 2014 and 2015, the ministry of housing and urban-rural development of China issued two documents on sponge city construction -- "technical guide for sponge city construction", "sponge city construction performance evaluation and assessment method (trial)". In October 2015, the general office of the state council promulgated the guiding opinions on promoting sponge city construction ${ }^{[4]}$. Zhenjiang became one of the first pilot cities in 2015. It was not until August 2017 that the first innovative government regulation on sponge city construction and management in Jiangsu province Zhenjiang sponge city management measures was officially implemented. The implementation of relevant policies and regulations on sponge city construction in Jiangsu province is not timely, which will greatly affect the process of sponge city construction. In addition, at the micro level, there is also a lack of detailed planning for the control of all sections and projects of sponge city construction in Jiangsu province, including construction time, path, implementation acceptance and later maintenance. And because of Regional differences, different construction projects in different pilot cities should have a strict technical standard. The technical standard is not clear, which is also a great challenge to the field operation of grass-roots managers, so it is difficult to guarantee the quality of sponge city construction.

\section{B. The concept cognition is insufficient}

Sponge city is similar to the concepts of "low-impact development" and "water-sensitive urban design". Although these concepts of rain-flood management have been relatively mature in foreign countries, the concept of "sponge city" has been introduced into China for only a few years. At present, according to the data of CNKI, there are less than 40 relevant research literatures on sponge city construction in Jiangsu province, and the research is still superficial. Public access to sponge cities is limited. The public's recognition of sponge city construction concept determines the degree of its active cooperation. The higher the recognition of sponge city construction concept, the better the cooperation degree will be. During the pilot investigation of Zhenjiang, it was found that residents did not pay attention to the construction of sponge city. Most residents only heard about the concept of "sponge city", but did not know about the design concept of sponge city. And residents had raised objections: as a result of the construction process, a large number of soil was dug out, it crowded out the roads of the community, especially in rainy days, resulted in muddy roads and brought inconvenience to the passage of the community. Therefore, residents believe that sponge city construction has not brought them benefits but has affected their life. This situation has reduced the residents' recognition of sponge city construction. Sponge city construction is a long-term project, it is difficult to see benefits in a short time. Therefore, insufficient cognition of sponge city construction concept will seriously affect the effect of sponge city construction.

\section{The management system is not sound}

At present, the construction and management of sponge city in Jiangsu province is still in its Initial stage. In terms of traditional rain-flood management, flood control and drainage are respectively responsible for water conservancy and municipal departments, with a clear division of labor. However, the construction of sponge city also requires the participation of multiple departments such as gardens, roads, environmental protection and water affairs. The more departments involved, the more difficult the management will be. As a result, the level of management directly determines the process and speed of sponge city construction. However, Jiangsu province only had the first sponge city construction pilot in 2015 , only three years ago, just in the Initial stage. There are some problems in construction, such as unclear division of responsibilities between departments, lack of effective communication, and insufficient attention to the construction of management system. The construction of sponge city in Jiangsu province is a huge project. The construction cycle is relatively long, the control in the construction process is not in place will directly affect the quality of sponge city construction, and even increase the time and capital cost. In the process of construction, multiple departments and agencies are required to communicate and cooperate. Each department and agency may have its own priorities to solve, so it cannot take into account other matters. Therefore, the construction of sponge city needs to have a special agency to communicate and coordinate with various departments. In addition, the promotion and education of sponge city construction are not enough for the public, the public's insufficient understanding of sponge city, and the low enthusiasm for participating in sponge city construction are also inseparable from the imperfect management system. The level of management directly determines the process of sponge city construction.

\section{Technical level is not in place}

The level of science and technology determines the quality and efficiency of sponge city construction. The influence of technical level on sponge city construction is mainly reflected in three aspects: The first is technical support. The level of technology determines the quality of sponge city construction, which can solve the technical problems in sponge city construction, so as to speed up the process of sponge city construction, save labor costs, and improve the comprehensive benefits of sponge city construction. The second is financial support. Science and technology are the primary productive forces, and technological level plays a crucial role in regional GDP. The number of industrial enterprises above the scale cannot be separated from technical support. In Jiangsu province, there were 23,564 industrial enterprises above the scale in 2016, an increase of 2022 over 2015. The more the number of industrial enterprises above the scale have, the 
greater the contribution to GDP. The government will have more funds to invest in sponge city construction. The third is innovation ability. Sponge city construction is a new concept of modern city construction, which urgently needs to stimulate the innovative consciousness of scientific researchers, build innovative teams and cultivate innovative ideas. There are 1.17 million scientific researchers in Jiangsu province in 2016, accounting for only $1 \%$ of the total population of Jiangsu province, indicating that the independent innovation ability of Jiangsu province still needs to be improved. In addition, to break through the traditional planning methods, the construction of sponge city needs to adapt to the hydrological characteristics of the site and constantly innovate. Jiangsu province has a large span between the north and the south, and there are huge differences in natural conditions. The construction of cavernous body in each city should be combined with its own conditions and local geological conditions. Moreover, the pilot cities' construction needs professional talents, and Jiangsu province still has a certain lack of sponge city construction team, which will hinder the process of sponge city construction.

\section{E. The differences in rainfall between the north and the south are great}

The geographical area of Jiangsu province has a large north-south span, and there are great differences in temperature, precipitation, geographical conditions, resource endowment and economic development. Precipitation in Jiangsu province shows obvious regional difference, which is reflected as more rainfall in the south, less rainfall in the north, more rainfall in the east and less rainfall in the west. In addition, the rainfall in the north is seriously unbalanced, mainly concentrated in summer, while in the south, the rainfall is more balanced throughout the four seasons, and floods often occur. For example, the annual rainfall of Xuzhou in 2016 is only 766.8 $\mathrm{mm}$, while that of Suzhou in 2016 is $1975.7 \mathrm{~mm}$, nearly three times as many as Xuzhou. The difference of soil, geological type and underground water level between north and south also affects the infiltration of rainwater. In addition, the different economic development levels between the north and the south of Jiangsu province also have a great impact on the investment in infrastructure construction and sponge city construction. For example, the per capita GDP of Suzhou in 2016 was 588.52 million yuan, while that of suqian in the north was only 235.112 million yuan.

\section{SOLUTIONS TO SPONGE CITY CONSTRUCTION IN JIANGSU PROVINCE}

\section{A. Strengthen top-level design and establish a sound management system}

In the construction of sponge city in Jiangsu province, the government should take the leading role, coordinate all relevant departments, draw lessons from the experience of rain and flood management in foreign developed countries, and combine the characteristics of its own urban development to formulate supportive policies and regulations suitable for itself, and formulate the relevant legal system of sponge city construction. Reasonable planning is of great guiding significance for sponge city construction. After Jiangsu province approved Nanjing, Xuzhou, Changzhou and Suzhou as provincial pilot cities, it should coordinate relevant institutions and departments to issue detailed plans for each pilot city and each construction sector on the basis of full analysis of the natural environment, economic development level and urban population of each city, including the construction path, implementation acceptance and later maintenance. At the same time, clear technical standards are also necessary to facilitate the grass-roots management personnel to check whether the construction process meets the requirements of the specification.

In order to solve the management problem of sponge city construction in Jiangsu province, the government needs to establish a perfect management system. The construction of a perfect management system needs to clarify the links involved in the construction process and the responsibilities each link should bear. Firstly, on the transverse, it is necessary to strengthen the coordination and cooperation among departments of landscape architecture, roads and water conservancy, focusing on the implementation and inspection of route planning, materials used and new technologies used in construction. Secondly, in the longitudinal, it is necessary to strengthen the communication and exchange between planning, evaluation, maintenance and other departments, so as to evaluate and feedback the performance of the pilot city construction, identify the maintenance subject, and carry out regular maintenance after the completion of the construction, so as to avoid the property loss caused by the lack of maintenance. Finally, a specialized agency needs to be established to coordinate and supervise the work between various departments. The main body of responsibility in sponge city construction should be clarified to avoid shirking responsibility among different departments. The supervision department can have the right to reward and punish the responsible subjects who violate the rules seriously in the construction process.

\section{B. Popularize the concept of construction, and improve the sense of identity of construction}

In order to effectively promote the construction of sponge city in Jiangsu province, it is necessary to set up the correct concept of sponge city construction. The acceptance and support of the public play an important role in promoting the construction of sponge city. Sponge city construction is "people-centered". The public should be aware of the concept of sponge city construction, which is specially designed to solve the urban water crisis, improve the urban ecological environment, form a virtuous cycle of water resources utilization, and avoid the loss of people's property and personal health caused by the disaster of rainwater. The public should fully realize that the construction of sponge city will bring huge benefits to themselves and the society. Specific measures can be taken with the help of the community committee to actively carry out relevant activities of sponge city construction with the community as the unit. For example, carrying out knowledge lectures and putting up propaganda slogans. It's very necessary to let the public realize the importance of sponge city construction and take an active part in the construction of 
sponge city. We can also set up some incentive measures to encourage the public to advice for sponge city, and let the public participate in the performance evaluation of sponge city construction to enhance the sense of ownership of residents. In addition, the government can also push the process and effect of sponge city construction with the help of official microblog and official accounts, so that the public can timely understand the dynamic of sponge city construction, and welcome the public to leave comments below.

\section{Raise technical level and guarantee construction specialization}

Science and technology are the primary productive forces, and the level of technology directly determines the resistance to change. The construction of sponge city requires the transformation from the single "drainage" of traditional city to "water absorption, storage, seepage and clean water", and then release the saved water for use when needed ${ }^{[5]}$. This poses a great challenge to the level of technology. Higher demand is rasied for enterprises in sponge city construction. Therefore, in the process of promoting sponge city construction in Jiangsu province, senior leaders should guide technological innovation and constantly introduce high-tech talents. Technological innovation needs financial support, and sponge city construction funds mainly come from the government. If the government wants to invest more funds in the construction of sponge city, it is necessary to increase fiscal revenue. For example, the proportion of tertiary industry in GDP can be appropriately increased. There are more sponge city construction pilots in Jiangsu province. Non-profit social groups and volunteer organizations can be introduced to alleviate the work pressure and financial pressure of the government by relying on third-party supervision and evaluation, while ensuring fairness and scientificity. As for high-tech talents, we can start from the following aspects: Firstly, Send relevant professionals overseas to study advanced concepts and technologies. Secondly, establish R \& D center, strengthen the research on sponge city construction through regular seminars, academic conferences and other ways, including the materials needed for construction, design ideas and etc, to explore the sponge city construction plan in line with the reality of Jiangsu province. Thirdly, the government provides free technical information on sponge city construction, which is available for free download by relevant people from all walks of life.

\section{Make reasonable plans and reduce regional differences}

In view of sponge city construction in Jiangsu province, we should make rational plans for the major differences between the north and the south regions. Due to the abundance of water resources in southern region, attention should be paid to the treatment of rainwater pollution and the control of runoff peak.
Due to the relative lack of rainwater resources in northern region, the utilization rate of rainwater resources should be paid attention to. As for the difference in economic level between the north and the south, the cooperation between enterprises in the north and the south can be strengthened, and the " funds " in the south can be transferred to the north. We will extensively absorb social funds and innovate financing channels to lay a foundation for the construction of sponge cities in the north.

\section{CONCLUSION}

In order to promote the construction of sponge city in Jiangsu province, this paper analyzes the actual situation of Jiangsu province, and concludes that there are five dilemmas in Jiangsu province, such as imperfect laws and regulations on sponge city construction, insufficient cognition of sponge city construction concept, insufficient management system, inadequate technical level and large regional differences between the north and the south. Therefore, the construction of sponge city in Jiangsu province should strengthen top-level design and establish a perfect management system, popularize the concept of construction and improve the sense of identity of construction, improve the technical level and guarantee the specialization of construction, make reasonable plans and reduce regional differences, which are expected to provide certain reference for the construction of sponge city in Jiangsu province.

\section{ACKNOWLEDGMENT}

This research was supported by Jiangsu qinglan project (Teacher Sue (2017) N0. 15), Jiangsu education department university philosophy and social science project (No. 2018SJZDI090) and Postgraduate Research \& Practice Innovation Program of Jiangsu Province (No. KYCX18_2066).

\section{REFERENCES}

[1] L. Li and F. Li, Key scientific problems and reflections on the construction of "sponge city" [J]. Acta Ecological Sonica, 2018, 38(7) (In Chinese)

[2] B. Zhang, Sponge city -- improving ecological environment [J]. Urban And Rural Construction, 2015(5). (In Chinese)

[3] J. Xu, TF. Ren and YH. Wang, Analysis on the comprehensive dynamic mechanism of sponge city construction -- a case study of Henan province [J]. Science And Technology Management Research, 2016, 36(6):192-198. (In Chinese)

[4] XZ. Liu and Y. Zhang. Construction of urban green space system based on the concept of "sponge city" [J]. Jiangsu Construction, 2016(02):3843. (In Chinese)

[5] LX. Xiao, Research on government responsibility in sponge city construction [D]. Central China Normal University, 2018. (In Chinese)

[6] HJ. Yu, DH. li, H. yuan et al. Theory and practice of "sponge city" [J]. Urban Planning, 2015, 39(6):26-36. (In Chinese) 